Research Article

\title{
Analysis of Competition Approach of Charter Airlines In Turkey According to The Miles and Snow's Competitive Typology
}

\author{
Hüseyin Önder Aldemir | Turkey, hoaldemir3572@gmail.com
}

\section{ABSTRACT}

Keywords:

Airline

Air Transportation

Airline Competition

Competitive

Approaches

The air transportation sector is one of the most strategic and vital sectors of the country in terms of economy (foreign trade, foreign-based income, etc.) and especially tourism; so it is critical that the industry be competitive and remain competitive both in the domestic and global markets. Nevertheless, the question of how Turkish airline companies deal with national and international competition and how they determine their competitive strategies is uncertain and has not been adequately addressed in the sectoral or academic context. There is also no clear and comprehensive literature in this regard. In this study, competitive approaches of the charter airlines making passenger transport were researched. By this means, charter airlines position in Turkish transportation present structure and competition of industry was also indirectly demonstrated. In the framework of this study, all charter airlines (Freebird, Corendon, and Tailwind) carrying passengers certified by Turkish General Directorate of Civil Aviation were included in the sample. In the survey, the data were gathered through qualitative research by interviewing senior executives of the airlines with structured questions. The secondary data used for the introduction of airlines were obtained from the internet sites of airlines. As a result of the interviews, it was concluded that an airline company appeared as Analyzer and the other two as Defenders in terms of competitive approaches according to the Miles and Snow Competitive Typology.
\end{abstract}

\section{Türkiye'deki Charter/Tarifesiz Havayollarının Rekabet Yaklaşımının Miles ve Snow'un Rekabet Tipolojisine Göre İncelenmesi}

\begin{tabular}{|c|c|}
\hline & öz \\
\hline $\begin{array}{l}\text { Anahtar Sözcükler: } \\
\qquad \text { Havayolu }\end{array}$ & $\begin{array}{l}\text { Hava taşımacılığı sektörü, ülkenin ekonomik (dış ticaret, yurt dışı gelir, vb.) açıdan yaşamsal ve özellikle turizm } \\
\text { açısından en stratejik sektörlerinden biridir; dolayısıyla sektörün rekabetçi olması ve hem iç hem de küresel pazarda } \\
\text { rekabetçi kalabilmesi kritik bir önem arz etmektedir. Buna rağmen, Türk havayolu işletmelerinin ulusal ve }\end{array}$ \\
\hline Hava Taşımacılığı & $\begin{array}{l}\text { sektörel ya da akademik bağlamda yeterince ele alınmamıştır. Ayrıca bu konuda kapsamlı ve net bir alanyazın } \\
\text { mevcut değildir. Bu çalışmada, Türkiye'de yolcu taşımacılığı yapmakta olan tarifesiz/charter havayollarının rekabet }\end{array}$ \\
\hline Havayolu Rekabeti & $\begin{array}{l}\text { yaklaşımları araştırılmış, rekabet yaklaşımlarının Türkiye'deki havayolu yolcu taşımacılığı sektörünün mevcut } \\
\text { durumu ve rekabet yapısı içerisinde nerede olduğu ortaya konulmuştur. Bu araştırma çerçevesinde Türkiye }\end{array}$ \\
\hline Rekabet & bağlamında yolcu taşımacılığı yapan, tüm charter uçuş yapan havayolları (Freebird, Corendon ve Tailwind) \\
\hline Yaklaşımları & $\begin{array}{l}\text { örnekleme dâhil edilmiştir. Araştırmada veriler, havayollarının üst düzey yöneticileri ile yapılandırılmış soruları } \\
\text { içeren görüşmeler yapılmak suretiyle nitel araştırma kapsamında toplanmıştır. Havayollarının genel tanıtımı için } \\
\text { kullanılan ikincil veriler, havayolu işletmelerinin internet sitelerinden elde edilmiştir. Yapılan görüşmeler sonucunda } \\
\text { toplam } 3 \text { charter havayolunun Miles ve Snow'un Rekabet Tipolojisi kapsamında bir havayolu işletmesinin Analizci, } \\
\text { diğer ikisinin ise Savunmacı bir rekabet anlayışı içerisinde olduğu sonucuna varılmıştır. }\end{array}$ \\
\hline
\end{tabular}

Cite this article as

Aldemir, H. Ö. (2018). Türkiye'deki Charter/Tarifesiz Havayollarının Rekabet Yaklaşımının Miles Ve Snow'un Rekabet Tipolojisine Göre İncelenmesi. Journal of Transportation and Logistics, 3(2), 53-62. doi: 10.26650/JTL.2018.03.02.01 


\section{Extended Abstract}

\section{Analysis of Competition Approach of Charter Airlines In Turkey According to The Miles and Snow's Competitive Typology}

Research Problem: The air transportation sector is one of the most strategic and vital sectors of the country in terms of economy (foreign trade, foreign-based income, etc.) and especially tourism; so it is critical that the industry be competitive and remain competitive both in the domestic and global markets. Nevertheless, the question of how Turkish airline companies deal with national and international competition and how they determine their competitive strategies is uncertain and has not been adequately addressed in the sectoral or academic context. There is also no clear and comprehensive literature in this regard.

Research Question: What are the competitive approaches of the charter/unscheduled airlines carrying passengers in Turkey?

Methodology: In the framework of this study, all charter airlines (Freebird, Corendon, and Tailwind) carrying passengers certified by Turkish General Directorate of Civil Aviation were included in the sample. In the survey, the data were gathered through qualitative research by interviewing senior executives of the airlines with structured questions. The secondary data used for the introduction of airlines were obtained from the internet sites of airlines.

Results and Conclusions: As a result of the interviews, it was concluded that an airline company appeared as Analyzer and the other two as Defenders in terms of competitive approaches according to the Miles and Snow Competitive Typology. Charter airlines operating in passenger transportation in the Turkish air transport sector do not follow the Prospector competition strategies and do not reflect the characteristics of leading strategies. The main reason of not having Prospector strategy in the sector might be Turkey's geopolitical and geostrategic position. X charter airline has a target of $75 \%$ retail sales (seat only) in its 10 -year vision of airline operations beyond being a charter airline in the aviation sector. At the same time, it has growth targets by increasing aircraft numbers every year. Because of these reasons, $X$ airline company was revealed as Analyzer in the result of the research while the other two charter airlines show all aspects of the Defender competitive approach due to their determination to maintain their existing structure as a stable. 


\section{Giriş}

Hava taşımacılığı, Türkiye için hayati öneme sahip sektörlerden biridir. Türkiye, Uluslararası Sivil Havacılığın temelini oluşturan “Uluslararası Sivil Havacılık Sözleşmesi - Chicago Sözleşmesi" ne 1945'te taraf olmuş ve Uluslararası Sivil Havacılık ÖrgütüICAO'nun kurucu üyelerinden biri olmuştur. Ayrıca, 1956 yılında Avrupa Sivil Havacılık Konferansı-ECAC üyesi olan Türkiye, Avrupa Hava Seyrüsefer Güvenliği Organizasyonu (EUROCONTROL) üyesidir. Illk Hava Taşımacılığı, 1933 yılında "Türk Hava Postaları" adı altında 5 uçağı kapsayan küçük boyutlu bir filo ile başlamıştır (http-1). Türk Hava Yolları, yıllarca sektörde tek aktör olarak rol üstlenmiştir. 1983 yılında sivil havacılık faaliyetlerinin yürütülmesi için çıkarılan 2920 sayılı Türk Sivil Havacılık Kanunu, serbest bir yolcu havayolu pazarının oluşturulması için kilit bir girişimdir. Bugün Türkiye'de yapılan havacılık faaliyetleri, 2920 sayılı Türk Sivil Havacılık Kanununa göre ve bu doğrultuda düzenlenen İdari, Teknik Düzenlemeler ve Havacılık Talimatları uyarınca yürütülmektedir. 2003 yılında devletin aldığı yeni bir karar ile hava taşımacılığında liberalizasyon dönemine geçilmiştir. Günümüzde rekabetçi bir piyasanın istenen seviyeye ulaştığını söylemek zor olsa da, 2003'ten bugüne kadar, özel havayolu şirketlerinin birçok faktörün etkisiyle iç ve dış yolcu trafiğindeki göstermiş olduğu gelişme önemlidir.

Hava araçlarıyla ticari amaçla, belirli hatlar üzerinde, ücret karşılığında yolcu veya yük veya yolcu ve yük taşıması yapan işletmeler ile ticari hava taşımacılığı kapsamında olmayan yolcu ve yük taşımacılığı ile ücret karşılığı olup olmadığına bakılmaksızın yapılacak hava işi ve eğitim faaliyetlerini yapan işletmeler hava taşıma işletmeleri olarak nitelendirilmektedir. Hava taşıma işletmeleri;

- havayolu,

- hava taksi,

- genel havacilık ve

- balon işletmeleri olmak üzere dört grupta toplanmaktadır (http-1).

En fazla on dokuz koltuk kapasitesine sahip Türk tescilli hava araçları ile ticari hava taşımacılığı yapan işletmeler "Hava Taksi iş̧letmeleri" olarak adlandırılmaktadır. Ülkemizde 51 adet Hava Taksi işletmesi bulunmaktadır.

Ticari hava taşımacılığı kapsamında olmayan yolcu ve yük taşımacılığı yapan işletmeler ile ücret karşılığı olup olmadığına bakılmaksızın önceden belirlenmiş bir hava sahasında ve belirlenmiş bir amaca yönelik olarak gerçekleştirilen operasyonları ve eğitim faaliyetleri yapan işletmeler "Genel Havacılık işsletmeleri" olarak adlandırılmaktadır.

Koltuk kapasitesi yirmi ve üzeri olan Türk tescilli uçaklarla yolcu taşımacılığı ile sadece yük taşımacılığı yapan ticari hava taşıma işletmeleri "Havayolu iş̧letmeleri" olarak adlandırımaktadır. Sivil Havacılık Genel Müdürlüğü tarafından ülkemizde ruhsatlandırılan tarifeli ve tarifesiz olmak üzere 13 havayolu işletmesi bulunmaktadır. Bu havayollarından 3 tanesi (ACT, ULS ve MNG) sadece yük taşımacılığı yapmaktadır, Borajet havayolu ise bölgesel taşımacılık yapmak maksadı ile kurulmuştur fakat 30 Aralık 2016 tarihinde operasyonlarını askıya almıştır. Uçuşlarına devam etmese de SHGM nezdinde işletme ruhsatı devam etmektedir (http-2). 
Bu çalışmanın konusunu oluşturan tarifesiz/charter havayolu işletmeleri ise Freebird, Corendon ve Tailwind olmak üzere üç adettir. Charter havayolları, yolcu hava taşımacılığı açısından ve turizm açısından ayrı bir öneme sahiptir ki, gerek tur operatörleri gerekse kendileri tarafından ülkenin tanıtımına katkılarının büyük olduğu da yadsınamayacak bir gerçektir.

Charter veya tarifesiz havayolu olarak isimlendirilen bu işletmeler, uçağın koltuklarının tümünü (full charter) veya belirli bir koltuk sayısını (split charter) tur şirketlerine veya turizm acentalarına satarak operasyonel sorumluluğu üstlenirler, yolcular ile direkt olarak muhattap değillerdir. Charter havayolları sezonsal olarak operasyonlarını icra etmektedirler. Kış sezonunda ise çalışmamaktadırlar. Bu periyodu ağırıklı olarak uçaklarını wet lease olarak kiralamak suretiyle geçirmektedirler. Tablo 1'de charter havayollarının sayfalarından alınan kısa tanıtıcı bilgilere yer verilmiştir. Charter/Tarifesiz havayolu işletmelerinin üçü de, Antalya Uluslararası Havalimanını operasyon üssü olarak kullanmaktadırlar.

Tablo 1. Sivil Havacılık Genel Müdürlüğü (SHGM) Tarafından Ruhsatlandırılan Tarifesiz/Charter Havayolu İşletmeleri.

\begin{tabular}{|l|l|l|l|}
\hline Havayolu Adı & Kuruluş Tarihi & Filo Yapısı & Genel Bilgiler \\
\hline Freebird & 2000 & 7 (A320) & $\begin{array}{l}\text { Gözen Holding'in bir işletmesidir. SHGM } \\
\text { tarafından, Yolcu/ Kargo Taşımacılığı, } \\
\text { Bakım Kuruluşu ve Eğitim Kuruluşu olmak } \\
\text { üzere 3 ayrı faaliyet alanında } \\
\text { yetkilendirilmiştir. }\end{array}$ \\
\hline Corendon & 2004 & $\begin{array}{l}\text { Avrupa AOC (Air Operator Certificate)'sinde } \\
\text { Corendon Dutch ve Corendon Europe } \\
\text { olmak üzere iki şirket de Corendon Group } \\
\text { çatısı altında uçuşlarını yapmaktadır }\end{array}$ \\
\hline Tailwind & 10 (B737-800) & $\begin{array}{l}\text { Türk ve Ingiliz ortaklığında İstanbul } \\
\text { merkezli olarak kurulmuştur. }\end{array}$ \\
\hline
\end{tabular}

Kaynak: SHGM ve havayolu işletmelerinin internet sayfaları (Erişim Tarihi: 07.08.2018)

Havayolu endüstrisi, bir ekonominin büyümesine katkıda bulunan en önemli sektörlerden biri olmasına rağmen, alanyazındaki akademik çalışmalar tatmin edici ve yeterli olmamakla beraber, endüstrinin dinamiklerini ve diğer kritik yönlerini yansıtmaktan çok uzaktır. Özellikle, rekabet gibi stratejik konular yeterince ele alınmamıştır. Türk havayolu sektörü hızla büyürken, sektörü dinamikleriyle anlamak hayati önemi haizdir. Bu anlayış sadece endüstri oyuncuları için değil, aynı zamanda sektörü kararlarıyla etkileyen düzenleyiciler için de önemlidir. Aldemir ve Şengür (2017), Türk havayolu şirketlerinin rekabetçi davranışları için bir alanyazın boşluğu olduğunu ortaya koymuştur.

Bu çalışmanın ana odak noktası, Miles and Snow'ın Rekabetçi Tipolojisine (Öncü, Savunmacı, Analizci ve Tepkici) göre Türk havayolu taşımacılığı sektöründe faaliyet gösteren tarifesiz/charter uçuş yapan işletmelerin (Freebird, Corendon ve Tailwind) rekabetçi yaklaşımını belirlemektir. Tarifesiz yolcu taşımacılığı yapan havayolu işletmelerinin rekabetçi yaklaşımını yöneticilerin gözünden ortaya koyabilmek maksadıyla, üç charter havayolu işletmesinden yedi üst düzey yönetici ile Miles ve Snow'un Rekabetçi Tipolojisinin özelliklerini yansıtan yapılandırılmış görüşmeler yapılmıştır.

Türkiye'de faaliyet gösteren charter havayollarının rekabet yaklaşımlarını ele alan bir akademik çalışmaya henüz alanyazında rastlanılmamıştır. Bu çalışma ile Türkiye'deki charter havayolu işletmelerinin rekabet yaklaşımları ile ilgili alanyazındaki önemli bir 
boşluğun dolduracağına inanılmaktadır. Aynı zamanda, sektörde faaliyet gösteren havayolları yöneticilerine de rekabet konusunda ışık tutacağı değerlendirilmektedir.

\section{Miles ve Snow'un Rekabet Tipolojisi}

Miles ve diğerleri (1978), işletme seviyesi strateji olarak isimlendirilen rekabet stratejilerinde bir tipoloji geliştirmişlerdir. Daha sonraları Miles ve Snow tipolojisi olarak anılan bu stratejinin dinamikleri ve kavramsal yapısı bazı araştırmacılar (Zahra ve Pearce, 1990; Gimenez, 1999; Gibcus ve Kemp, 2003; Martins ve Kato, 2010; Obel ve Gurkov, 2013 vb.) tarafından incelenmiş ve teorik yönü ile ilgili vurgular yapılmıştır. Bu tipoloji, çok fazla araştırmacı (Bustamam ve Pech, 2016; Anwar, Shah ve Hasnu, 2016 vb.) tarafından ise uygulama sahasında endüstrideki farklı işletmelerin rekabet stratejilerini ortaya koymak maksadıyla kullanılmış ve kullanılmaktadır. Miles ve Snow'un tipolojisi, inceleme ve geçerlilik yönünden Ghoshal (2003), Hambrick (2003) ve Ketchen (2003) tarafından farklı çevre düzenlerinde test edilmiştir. Bu tipoloji, farkı endüstrilerden farklı büyüklükteki işletmelerin strateji-performans ilişkisini araştırmak açısından özellikle daha uygundur (Anwar ve diğerleri, 2016).

Miles ve Snow (1978), uyum döngüsü ve stratejik tipolojiden oluşan bir teorik çerçeve geliştirmişler ve bu teorik çerçeveyi, var olan yönetim teorileriyle ilişkilendirmişlerdir. Tipolojileri 4 stratejik tipi içermektedir. Bunlar; savunmacı, öncü, analizci ve tepkici stratejilerdir.

Miles ve diğerleri (1978) meydana getirdikleri bu sistemi, varolan alanyazın ile ders kitapları basımı, elektronik, gıda işleme ve sağlık endüstrilerinde yapılan çalışmaları yorumlayarak oluşturmuşlardır. Yapılan bu çalışmada "uyum döngüsü" (adaptive cycle) olarak adlandırdıkları bir uyum sürecini geliştirmişlerdir. Buna göre, örgütün davranışlarının sadece bir kısmı çevresel koşullar tarafından önceden belirlenmiştir. Üst yönetim tarafından yapılan seçimler, organizasyonun yapısı ve süreci açısından esas kritik öneme sahip olanlardır. Miles ve Snow (1978)'a göre organizasyonun başarısı dış (çevre) ve iç (strateji, yapı, süreç ve ideoloji) uyumuna dayalıdır (2010, Martins ve Kato). Bu süreç, müşterilerin şu anki ve gelecekteki ihtiyaçlarına cevap vermek için organizasyonun pazara uyum sağlaması ile başlamaktadır. Bu uyum işletmenin stratejisini oluşturur. Başka bir ifade ile bu tip bir analiz; strateji, yapı ve süreç arasındaki ilişki üzerinde çalışarak organizasyonun değişen çevreye uyumunu değerlendirmeye çalışmaktadır (1978, Miles ve Snow). Uyum döngüsü olarak adlandırılan ve rekabetçi çevreye uyumu içeren bu stratejinin aşamaları aşağıdaki sorulara verilen çözümlerden oluşmaktadır (1978, Miles ve diğerleri):

- Girişim ile İlgili (Entrepreneurial) Problem: Ürün-pazar alanı, başarı durumu, çevre ve büyüme politikalarını izleme;

- Mühendislik (Engineering) Problemi: Teknolojik hedefler, teknolojik kapsam ve teknolojik oryantasyon;

- Yönetimsel (Administrative) Problem: Ana idari fonksiyon, planlama tutumu, örgütsel yapı ve kontrol.

Zahra ve Pearce (1990), Miles ve Snow'un tipolojisini 3 ana temele dayandırmışlardır. Birincisi, başarılı örgütlerin zaman içerisinde çevresel uyum için sistematik ve tanımlanabilir bir yaklaşım geliştirmiş olduklarıdır. Miles ve Snow'un tipolojisi, uyum 
döngüsü ile örgüt davranışının genel fizyolojisini, uyumun ana unsurlarını kavramsallaştırması ve bunlar arasındaki ilişkiyi göz önüne getirmesi ile açıklığa kavuşturmuştur. İkinci dayanak, ortaya koymuş oldukları dört stratejinin endüstrinin içinde var olmasıdır. Bu stratejiler arasındaki temel farklılık, örgütün etki alanının değişim hızıdır. Üçüncüsü ise; savunmacı, öncü ve analizci stratejilerin uygun olarak tatbik edilmesi durumunda etkin bir performansa götürecek olmasıdır. Çoğunluğu uyum döngüsünün üç unsuru arasındaki iç tutarlılığa dayanmaktadır. Her tip sürdürülebilir, farklı yetkinlikler üretebilmek için farklı fonksiyonları vurgulamaktadır. Tepkici tip, tutarlı stratejiden yoksundur. Sonuç olarak, tipoloji savunmacı, öncü ve analizcilerin tepkicilerden daha üstün olacağını ileri sürmektedir.

Gimenez (1999), küçük iş̧letmeler bağlamında Miles ve Snow'un rekabet stratejileri modelini uyguladığı bir çalışma yapmıştır. Miles ve Snow'un jenerik stratejilerinin taksonomisi ile ilgili ampirik kanıtların gözden geçirilmesi sonucunda, çeşitli çevresel koşullarda dört farklı jenerik stratejinin mevcut olduğu önermesine güçlü bir destek sağlanmakta olduğu sonucuna varmıştır. Gimenez (1999); dinamik ortamlarda daha fazla öncü stratejiler hâkimken, savunmacı işletmelerin daha istikrarlı sanayilerde baskın olacaklarını ortaya koymuştur. Dört stratejik tip arasındaki performans farklılıklarıyla ilgili çelişkili kanıtlar olduğu bildirilmiştir. Hem iç hem de dış doğadaki, işletme büyüklüğü veya çevresel türbülans gibi değişkenlerin bu ilişkiyi etkileyebileceği düşünülmektedir.

Miles ve Snow'un ortaya koymuş olduğu rekabet tipolojisinin özeti Tablo 2'de gösterilmiştir.

Tablo 2. Miles ve Snow'un rekabet tipolojisinin özeti

\begin{tabular}{|l|l|}
\hline Stratejik Durum & Ana Odak \\
\hline Öncü & $\begin{array}{l}\text { Girişimci, yenilikçi ve yeni } \\
\text { fırsat odaklı }\end{array}$ \\
\hline Savunmacı & $\begin{array}{l}\text { Mevcut piyasayı savunur } \\
\text { (çoğunlukla niş bir pazar) } \\
\text { Öncü ve savunmacı } \\
\text { tiplerin hibridi }\end{array}$ \\
\hline Analizci & Değişime tepki gösterir. \\
\hline Tepkici &
\end{tabular}

\section{Özellikler}

Dış oryantasyon, çevre tarama, yeni fırsatları en üst düzeye çıkarma.

Pazar ihtiyaçlarını karşılamak için yenilikçi.

Esneklik ve işletme kural ve yönetmeliklerinin sınırlamalarından özgür hareket etme. Değişimi memnuniyetle karşılar ve çevreyi "belirsiz" olarak görür.

Dar ürün / hizmetler yelpazesi.

Verimlilik önlemlerine dayalı iç oryantasyon ve gereksiz risklerden kaçınma. Merkezi kontrol ve fonksiyonel bir yapı yaygındır.

Kararlı ve dinamik pazarlarda iyi çalışır. Durağan piyasalarda etkinlik ve artan üretim kullanır ve dinamik pazarlarda yenilikler yapar.

Kısa vadeli planlama, başkalarının eylemlerine tepki verir. Değişiklik kaçınılmaz olarak bazı güçlüklerle karşılanır.

Kaynak: O'Regan \& Ghobadian (2005)'dan uyarlanmıştır.

\section{Yöntem}

Bu çalışmada, Türkiye'de faaliyet gösteren tarifesiz havayolu yolcu taşımacılığı yapan işletmelerin rekabet yaklaşımlarını incelemek üzere nitel araştırma modeli kullanılmıştır.

Araştırmada veriler, tarifesiz havayollarının üst düzey yöneticileri ile çoktan seçmeli sorular yöneltilmek suretiyle görüşmeler yapılarak ve havayolu işletmelerinin internet siteleri olan ikincil kaynaklara dayanarak nitel araştırma kapsamında toplanmıştır.

Görüşmelerde, Miles ve Snow'un rekabet tipolojisinin Türk hava taşımacılığı sektöründe nasıl bir uygulama alanı bulduğu 12 adet yapılandırılmış soru ile tespit edilmeye çalışılmıştır. Görüşme formunun giriş kısmında görüşmeciyi tanımaya yönelik birtakım sorular ile araştırmanın amaç ve içeriğini belirten ve görüşmenin 
bilimsel amaçlarla kullanılacağını içeren açıklamalar bulunmaktadır. Diğer bölümde ise Miles ve Snow'un rekabet yaklaşımlarından hangisinin uygulandığını ortaya koymaya çalışan 12 adet çoktan seçmeli bir soru seti bulunmaktadır.

Görüşme sorularının gerek hazırlık aşamasında gerekse sonrasında, Yönetim Ana Bilim Dalı ve Sivil Havacılık Yönetimi Ana Bilim Dalı alanlarında uzman öğretim üyeleri tarafından içerik incelenmeleri ve gerekli düzeltmeler, geri beslemeler yapılmıştır. Görüşme soruları için yöntem konusunda uzman bir öğretim üyesi ile görüşülmüş ve sorularda gerekli düzeltmeler yapılmıştır.

Görüşme yapılacak olan kişilere imzalatılmak üzere “Görüşmeye Gönüllü Katılım Formu" hazırlanmıştır. Bu form da yöntem konusunda uzman hoca tarafından kontrol edilmiş ve onaylanmıştır.

Görüşme formuna akademik olarak son şekil verilmesini müteakip, havacılık sektöründen 2 kişiden randevu alınmak suretiyle birer hafta ara ile pilot görüşmeler gerçekleştirilmiş ve gerekli düzeltmeler yapılarak görüşme formuna son şekli verilmiştir.

Türkiye'de sertifikalandırıımış üç Tarifesiz havayolu (Freebird, Corendon ve Tailwind) örnekleme dâhil edilmiştir. Çalışma konusu tarifesiz havayolu işletmelerinde rekabet yaklaşımları olduğundan dolayı, görüşme yapılmak istenen hedef kitle ağırlıklı olarak havayolu işletmelerinin üst düzey yöneticileri (Genel Müdür veya Yardımcıları, Stratejik Planlama, Kurumsal Planlama, Ticaret ve Pazarlama departmanlarının başındaki yöneticiler) olmuştur. Toplam 7 üst düzey yönetici ile görüşmeler İstanbul ve Antalya'daki havayolu işletmelerinin merkezlerinde icra edilmiştir.

Yapılan görüşmeler ortalama 1 saat 30 dakika civarında sürmüştür. Görüşme yapılırken bir görüşme formu, yöneticilerin de soruları takip edebilmesi maksadıyla yöneticilerin önünde hazır bulundurulmuştur. Bu esnada görüşülen yöneticiden ses kaydı için cihaz kullanılması için izin istenmiştir. Her ne kadar sorular çoktan seçmeli olsa da, görüşülen personel yaptığı açıklamalar ile daha detaylı ve aydınlatıcı bilgiler vermişlerdir.

\section{Bulgular}

Bu çalışmada, Türkiye'de Sivil Havacılık Genel Müdürlüğü tarafından tescil edilmiş tarifesiz/charter havayolları olan Freebird, Corendon ve Tailwind havayollarının rekabet yaklaşımları, Miles ve Snow'un Rekabet Tipolojisine göre ortaya konmaya çalışıımıştır. Bu üç havayolundan yedi üst düzey yönetici ile yapılan görüşmede Miles ve Snow'un tipolojisi ile ilgili 12 yapılandııımış/çoktan seçmeli soru sorulmuştur. Aynı havayolu işletmesinden birden fazla yönetici ile yapılan görüşmeler konsolide edilerek havayolu işletmesi görüşü olarak tek bir cevap haline getirilmiş ve Tablo 3 oluşturulmuştur.

Havayolu işletmelerine $X, Y$ ve $Z$ harflerinden oluşan kodlar verilmiştir. Miles ve Snow'un rekabet tipolojisi içerisinde yer alan Öncü (Ö), Analizci (A), Savunmacı (S) ve Tepkici (T) yaklaşımlar baş harfleri ile temsil edilmişlerdir. Tablo 3'deki ilk sütunda havayolu işletmelerindeki yöneticilere yöneltilen sorular, ilk satırda ise havayollarının kodlarına yer verilmiştir. Tablonun içerisinde her yetkilinin vermiş olduğu cevap, 
havayollarının altında ve yöneltilen sorunun karşısında yer alan kutucuğun içerisinde yer almıştır.

Tablo 3. Havayolu işletmelerinin üst düzey yöneticileri ile gerçekleştirilen yapılandırılmış görüşme sonuçları

\begin{tabular}{|c|c|c|c|c|}
\hline Tablo 3. Havayolu işletmelerinin üst düzey yöneticileri ile gerçekleştirilen yapılandırılmış görüşme sonuçlan \\
\hline$X$ & $Y$ & $Y$ \\
\hline
\end{tabular}

1.isşletmenizdeki rekabet stratejileri ile ilgili üst düzey yönetimin rolünü aşağıdakilerden hangisi en iyi tanımlar?

2.İşletmenizi aşağıdaki ifadelerden hangisinin en iyi tanımladığını düşünüyorsunuz?

3.İşletmenizin teknolojik gelişmelere ve yeniliklere bakış açısını aşağıdakilerden hangisi en iyi tanımlar?

Yöneticiler, çalkantılı ve

4. İşletmenizde idari yapıdaki en güçlü ve en fazla söz sahibi olanlar kimlerdir?

5.İşletmenizde planlama faaliyetlerinin niteliğini aşağıdaki ifadelerden hangisi en iyi şekilde tanımlamaktadır?

6.Işletmenizin koordinasyon mekanizması nasıl çalışmaktadır?

7.Iş̧letmenizin kontrol mekanizması nasıl çalışmaktadır?

\section{8.Örgütsel performansınızı nasıl} ölçmektesiniz?

9.İ̧sletmenizin dış çevre ile olan ilişkisini aşağıdakilerden hangisi en iyi tanımlamaktadır?

10.Işsletmenizin büyüme ile ilgili tutumu nedir?

11.Sektörde işletmeniz açısından risk olarak aşağıdakilerden hangisini görmektesiniz?

12.Bugün ve gelecekte işletmenizin çevresel koşulları değerlendirmek suretiyle ortaya koyacağı tavrı aşağıdakilerden hangisi en iyi ifade etmektedir? dinamik pazarlarda rakiplerini yeni fikirler bulmak için yakından izler ve en makul olanları hızla benimserler (A)

Değişimi takip eder, uygulamaya çalışırız, yenilikleri destekleriz ve esnek davranış tarzımız vardır. (Ö)

Düşük maliyetli teknolojileri kullanırız. Etkinliği sürdürebilmek için teknolojide sürekli gelişimi ararız. (S)

Yöneticiler çevredeki değişim ve belirsizlikleri her zaman için algılar ancak etkili tepki veremezler. (T)

Verimliliği ön planda tutar ve gereksiz risklerden kaçınırız. (S)

Hem uygulanan pazarda hem de dinamik pazarlarda kullanılabilecek teknolojileri tercih ederiz. Çok sayıda ve etkili/başarılı bir mühendis ekibimiz vardır. (A)

Pazarlama uzmanları ve mühendisler $(A)$

Durağan pazarlarlar (sabit olan tarifeli hatlar) için hizmet üretimi ile pazarlama arasında yoğun bir ortak planlama, yeni pazar ve ürünler için ise pazarlama, mühendislik ve hizmet üretimi arasında kapsamlı bir planlama mevcuttur. (A)

Oldukça gelişmiş bir koordinasyon mekanizması bulunmaktadır Bazı çatışmalar ilgili müdürler tarafından, bazıları ise hiyerarşik düzen içerisinde çözüme kavuşturulur. (A) Hem dikey hem de yatay geri bildirime sahip katı olmayan bir merkezi kontrol sistemimiz vardır. (A)

Performans

değerlendirilmesi etkinlik ve verimliliğe dayanır. (A)

Dış çevre değişimlerini ve koşullarını yoğun bir şekilde takip ederiz. (Ö)

Pazara nüfuz etme ve ürünpazar gelişimi ile istikrarlı bir büyümeyi öngörmekteyiz. (A)

Örgüt yapısı ve strateji uyumsuzluğu neticesinde etkin olmayan ve verimsiz bir işletmeye dönüşme $(A)$ Hem durağan hem de dinamik pazar koşullarında denge kurmayı başarabilmek için işletme yapısında uygun farklılaşmaya gideriz. (A)

Maliyet kontrol/ finans ve üretim uzmanları (S)

Planlama; yoğun, maliyet odaklıdır ve uygulama safhasından önce sonlandırılır. (S)
Basit koordinasyon mekanizması mevcuttur. Çatışmalar hiyerarşik kanallar tarafından çözümlenir. (S)

Merkezi kontrol ile uzun ve hiyerarşik bir bilgilendirme sistemimiz vardır. (S)

Örgütsel performans önceki yıllara göre ölçülür. (S)

Dış çevre değişimlerini ve koşullarını yoğun bir şekilde takip ederiz. (Ö)

Öncelikli olarak pazara nüfuz ederek temkinli ve artan bir büyümeden yanayız. (S)

Sektördeki kritik değişimlere ayak uyduramama sonucunda verimsizliğe sürüklenme (S)

Hem durağan hem de dinamik pazar koşullarında denge kurmayı başarabilmek için işletme yapısında uygun farklılaşmaya gideriz. (A)

Yöneticiler işletmenin çalışma alanlarında oldukça uzmandır ancak kendi pazarları dışında yeni fırsatlar aramaya meyilli değildirler. (S)

Diğer havayolu işletmelerinin davranışlarını izlemekle yetiniriz, planlarımız ise kısa vadelidir. (T)

Diğer havayollarının kullandıkları teknolojilerden bünyemize uygun olanı alır ve uygularız. (T)

Öne çıkan kişi ya da gruplar yoktur.

Planlama; yoğun, maliyet odaklıdır ve uygulama safhasından önce sonlandırılır. (S)

Basit koordinasyon mekanizması mevcuttur. Çatışmalar hiyerarşik kanallar tarafından çözümlenir. (S)

Hem dikey hem de yatay geri bildirime sahip katı olmayan bir merkezi kontrol sistemimiz vardır. (A)

Örgütsel performans önceki yıllara göre ölçülür. (S)

Dış çevre değişimlerini ve koşullarını yoğun bir şekilde takip ederiz. (Ö)

Öncelikli olarak pazara nüfuz ederek temkinli ve artan bir büyümeden yanayız. (S)

Risk değerlendirmesi etkili şekilde yapılamadığından yönetsel ve finansal sıkıntılara sürüklenme $(T)$ Bugünkü pazarın gereklerini tam olarak karşılarız zira "yarın da bugüne benzer olacaktır" yaklaşımıyla hareket ederiz. (S) 
Yukarıdaki tablo incelendiğinde Türk havacılık sektöründeki tarifesiz/charter havayolu işletmelerinin Miles ve Snow'un tipolojisine göre Analizci veya Savunmacı bir yaklaşım içerisinde oldukları görünmektedir. Özellikle 9. soruya tüm charter havayolu işletmelerinin üst düzey yöneticileri Öncü stratejilere uygun cevap vermiş olsa da, bu havayolu işletmeleri için "Öncü stratejileri uygulamaktadır" çıkarımı yapılamaz. Bu özellik salt olarak öncü stratejileri uyguladıkları anlamına da gelmemektedir. Havayollarının dış çevreyi çok iyi gözlemledikleri ve takip ettikleri Öncü tipolojinin bir özelliği olsa da, sektörde öncü olmak için gereken şartları taşımadıkları diğer sorulara vermiş oldukları cevaplardan anlaşılmaktadır.

Havayolu işletmelerini Miles ve Snow'un Rekabet Tipolojisinde konumlandırmak maksadı ile sorulan yapılandııılmış görüşmenin 12 sorusunda verilen cevaplar 9. soru dışında ağırlıklı olarak havayolu işletmelerinin Analizci veya Savunmacı rekabet yaklaşımları benimsemiş olduklarını ortaya çıkarmıştır.

Miles ve Snow'un tipolojisinden hangisini veya hangilerini kullandıklarına dair 12 sorudan alınan cevaplar sonucunda oluşan ve ilgili tipolojilere yanıtların uygun düşen frekans dağılımı ise Tablo 4'te sunulmuştur.

Tablo 4. Havayollarının Miles ve Snow'un Rekabet Tipolojisine göre frekans dağılımı

\begin{tabular}{|l|c|c|c|}
\hline & $\mathbf{X}$ & $\mathbf{Y}$ & $\mathbf{Z}$ \\
\hline Öncü (Ö) & 2 & 1 & 1 \\
\hline Analizci (A) & $\mathbf{9}$ & 2 & 1 \\
\hline Savunmacı (S) & 1 & $\mathbf{8}$ & $\mathbf{6}$ \\
\hline Tepkici (T) & - & 1 & 3 \\
\hline Diğer & - & - & 1 \\
\hline Baskın Tipoloji & A & S & S \\
\hline
\end{tabular}

Tablo 4 incelendiğinde Türk havacılık sektöründe yolcu taşıyan charter havayolu işletmelerinin Miles ve Snow'un rekabet tipolojilerindeki özelliklerden birini net yansıttıklarını görmekteyiz. X havayolu işletmesi Analizci bir rekabet stratejisi benimsemişken, $Y$ ve $Z$ havayolu işletmeleri Savunmacı bir yaklaşım içerisindedirler. $X$ havayolu işletmesinin 10 yıllık vizyonunda \%75 ve üzeri perakende satışlar (seat only) ile havacılık sektöründe charter dışında var olma hedefi bulunmakta olduğu görüşme yapılan yöneticilerin ifadelerinden öğrenilmektedir. Aynı zamanda $\mathrm{X}$ havayolu işletmesinin her yıl büyüme hedefi bulunmaktadır. Bu da sektör içerisinde bulunan diğer 2 charter işletmesinden daha farklı bir rekabet yaklaşımı içerisinde bulunmasının sebebidir.

\section{Sonuçlar ve Tartışma}

$\mathrm{Bu}$ çalışma Türk tescilli tarifesiz/charter havayolu işletmelerinin rekabet yaklaşımlarından hangilerini uyguladıklarını ortaya koyma hedefi ile tasarlanmıştır. Başlangıçtan beri özel sektör mantığı ile rekabet eden tarifesiz havayolu işletmelerinin üst düzey yöneticilerinin görüşleri doğrultusunda sonuçlar elde edilmiştir.

Charter havayolu işletmelerinin, Miles ve Snow'un tipolojisi açısından değerlendirildiğinde kararlı bir yapı gösterdikleri anlaşılmaktadır. Analizci olan charter havayolunun bu yaklaşımda bulunmasının sebebi iş modelini değiştirerek, büyüme stratejisini belirlemesidir. Diğer iki charter havayolu işletmesi ise, stabil olarak mevcut yapısını sürdürme konusunda kararlılıklarından dolayı Savunmacı yaklaşımın özelliklerini ağırlıklı olarak göstermektedirler. 
Charter havayollarının yöneticileri full charter modelinin dünyada kısa sürede bırakılacağını, tarifesiz havayollarının da pek çoğunun split charter modelini uyguladıklarını yapılan görüşmelerde ifade etmişlerdir.

Charter havayolları sezonsal olarak faaliyet gösterdiklerinden dolayı, kış döneminde wet lease olarak uçaklarını kiralamaktadırlar. Devlet eliyle turizm sezonunun 12 aya yayılmasının sağlanması ile sadece turizm sektöründe değil, havacılık sektöründe de bir yoğunluk ve kârlılık olacaktır. Bu sayede charter işletmelerinin de kış sezonunda harekât yapmasının önü açılacak ve sezonsalıı sona ererek yılın her günü yolcu taşıyabilecek hale geleceklerdir.

Niş hatları önce charter uçuş yapan havayolu işletmelerinin tespit ettiği eğer pazar kârlı ise müteakiben diğer tarifeli havayollarının bu hatlara girdiği ve pazara ortak oldukları ifade edilen önemli hususlardan bir tanesidir. Charter havayolları bu durumdan şikayetçilerdir ve üst otoritelerin bu durumu charter havayollarının lehine koruyacak şekilde rekabet tedbirlerini alması gerektiğini değerlendirmektedirler. Tarifeli havayollarının da yer yer bazı hatlarda tur şirketleri ile anlaşmak suretiyle charter uçuşlar yaptıkları yapılan görüşmelerden anlaşılmaktadır. Bu durum ise, charter havayolları açısından olumsuz olarak karşılanmaktadır.

\section{KAYNAKÇA}

Aldemir, H.Ö. and Şengür, F., (2017). Academic foundations of air transportation research in an emerging country: A bibliometric analysis. International Journal of Aviation Systems, Operations and Training, 4 (1), $15-27$.

Anwar, J., Shah, S., and Hasnu S., (2016). Business strategy and organizational performance: measures and relationships. Pakistan Economic and Social Review, 54 (1), 97-122.

Bustamam, U.S.A. and Pech, R., (2016). An examination of Malay business growth strategies using Miles and Snow's strategic typology. Scientific Cooperations 2nd International Conference on Social Sciences, Istanbul-Turkey.

Gibcus, P. and Kemp, R.G.M. (2003). Strategy and small firm performance. Research Report H200208, SCALES Scientific Analysis of Entrepreneurship and SMEs, Zoetermeer.

Gimenez, F.A.P. , 1999. Miles and Snow's strategy model in the context of small firms.

Martins, T.S. and Kato, H.T., (2010). An analytical framework for Miles and Snow typology and dynamic capabilities. XXXIV Encontro da ANPAD, Rio de Janeiro.

Miles, R.E., Snow, C.C, Meyer, A.D. and Coleman Jr., H.J. , (1978). Organizational strategy, structure, and process. The Academy of Management Review, 3 (3), 546-562.

Miles, R.E. and Snow, C.C., (1978). Organizational strategy, structure, and process. New York: McGraw-Hill.

Obel, B. and Gurkov, I.B., (2013). Revisiting Miles-Snow typology of strategic orientation using stakeholder theory. ICOA Working Papers Series, 2013-02, Aarhus University, Business and Social Sciences, Interdisciplinary Center for Organizational Structure.

O'Regan, N. ve Ghobadian, A., (2006). Perceptions of generic strategic of small and medium sized engineering and electronics manufacturers in the UK: the applicability of the Miles and Snow typology. Journal of Manufacturing Technology, 17 (5), 603-620.

Zahra, S.A. and Pearce II, J.A., (1990). Research evidence on the Miles-Snow typology. Journal of Management, 16 (4), 751-768.

http-1: http://web.shgm.gov.tr/en/kurumsal/1-history (Erişim Tarihi: 17.07.2018)

http-2: http://web.shgm.gov.tr/tr/havacilik-isletmeleri/2063-hava-tasima-isletmeleri (Erişim Tarihi: 07.08.2018) 